\title{
PENERAPAN MODEL PEMBELAJARAN KOOPERATIF TIPE MAKE A MATCH UNTUK MENINGKATKAN HASIL BELAJAR PKn SISWA KELAS III SD NEGERI 188 PEKANBARU
}

\author{
Iggo Mayyudin Nugroho \\ mayyudinigo@yahoo.com \\ Program Studi Pendidikan Guru Sekolah Dasar \\ Universitas Riau, Indonesia
}

\section{ARTICLE INFO}

Submitted:

12 Juli 2019

$12^{\text {th }}$ July 2019

Accepted:

7 Oktober 2019

$7^{\text {th }}$ October 2019

Published:

10 Oktober 2019

$10^{\text {th }}$ October 2019

\section{ABSTRACT}

\begin{abstract}
This research is in the background by the low learning outcomes of PKn-grade III students Negeri Elementary School 188 Pekanbaru, with an average class of 68.25. While the value of 40 students are only 17 students who achieve the minimum submission criteria. This research is a class action research conducted aims to improve the learning outcomes of PKn-grade III students Negeri Elementary School 188 Pekanbaru by applying a cooperative model of make a match type. The subject of this study is a grade III student of State Elementary School 188 Pekanbaru year 2018/2019. The data collection instruments on this thesis are teacher activity sheets and student activities and learning outcomes. This thesis presents the data of the learning outcomes obtained from the average learning results before the 68.25 action increased by $12.63 \%$ on average to 76.87 on the I cycle. In the II cycle it increased to $19.41 \%$ with an average of 81.5 . Teacher activity on first meeting cycle I gained a percentage of $62.5 \%$ of the category enough, at the second meeting experienced an increase by a percentage of $79.16 \%$ good category. Next cycle II first meeting of teacher activity also experienced an increase with a percentage of $83.33 \%$ good category, and the second meeting experienced another increase by the percentage of $95.83 \%$ very good category. In the results of the study, students began to understand the course of PKn lessons after they had the cooperative model of the Make a match type marked with increased teacher activity and student activities and the results of learning on each cycle. The results of the research in class III of State Elementary School 188 Pekanbaru proved that the implementation of model cooperative type make a match can be a result of learning the results of PKn-grade III students Negeri Elementary School 188 Pekanbaru.
\end{abstract}

Keywords: cooperative model type make a match, study results PKn

Abstrak: Penelitian ini di latar belakangi oleh rendahnya hasil belajar PKn siswa kelas III Sekolah Dasar Negeri 188 Pekanbaru, dengan rata-rata kelas 68,25. Sedangkan nilai dari 40 siswa hanya 17 siswa yang mencapai kriteria ketuntasan minimal (KKM). Penelitian ini merupakan Penelitian Tindakan Kelas (PTK) yang dilakukan bertujuan untuk meningkatkan hasil belajar PKn siswa kelas III Sekolah Dasar Negeri 188 Pekanbaru dengan menerapkan model kooperatif tipe make a match. Subjek penelitian ini adalah siswa kelas III Sekolah Dasar Negeri 188 Pekanbaru tahun ajaran 2018/2019. Instrumen pengumpulan data pada skripsi ini adalah lembar aktivitas guru dan aktivitas siswa serta hasil belajar. Skripsi ini menyajikan data hasil belajar yang di peroleh dari rata-rata hasil belajar sebelum tindakan 68.25 meningkat $12.63 \%$ rata-rata menjadi 76.87 pada siklus I. Pada siklus II meningkat menjadi $1.41 \%$ dengan rata-rata 81,5 . Aktivitas guru pada siklus I pertemuan pertama memperoleh persentase sebesar $62.5 \%$ kategori cukup, pada pertemuan kedua mengalami peningkatan dengan persentase $79.16 \%$ kategori baik. Selanjutnya siklus II pertemuan pertama aktivitas guru juga mengalami peningkatan dengan persentase $83.33 \%$ kategori baik, dan pertemuan kedua mengalami peningkatan lagi dengan persentase $95.83 \%$ kategori sangat baik. Pada hasil penelitian ini siswa mulai memahami materi pelajaran PKn setelah menerapakan model kooperatif tipe make a match di tandai dengan peningkatan aktivitas guru dan aktivitas siswa serta hasil belajar pada setiap siklusnya. Hasil penelitian di kelas III Sekolah Dasar Negeri 188 Pekanbaru membuktikan bahwa penerapan model kooperatif tipe make a match dapat menigkatkan hasil belajar PKn siswa kelas III Sekolah Dasar Negeri 188 Pekanbaru.

Kata Kunci: model kooperatif tipe make a match, hasil belajar PKn

Nugroho, I.M. (2019). Penerapan Model Pembelajaran Kooperatif Tipe Make a Match untuk Meningkatkan Hasil Belajar PKn Siswa Kelas III SD Negeri 188 Pekanbaru. Primary: Jurnal Pendidikan Guru Sekolah Dasar, $8 \quad$ (2), 148-159. $\quad$ DOI: http://dx.doi.org/10.33578/jpfkip.v8i2.7627. 


\section{PRIMARY : JURNAL PENDIDIKAN GURU SEKOLAH DASAR \\ Volume 8 Nomor 2 Oktober 2019 \\ DOI : http://dx.doi.org/10.33578/jpfkip.v8i1.7627 \\ ISSN : 2303-1514 | E-ISSN : 2598-5949 \\ https://primary.ejournal.unri.ac.id/index.php/JPFKIP}

\section{PENDAHULUAN}

Menurut Permendiknas No. 22 Tahun 2006 (Ernawati, Utami, \& Sabri, 2015) mengemukakan bahwa mata pelajaran Pendidikan Kewarganegaraan merupakan mata pelajaran yang memfokuskan pada pembentukan warga negara yang memahami dan mampu melaksanakan hakhak dan kewajibannya untuk menjadi warga Negara Indonesia yang cerdas, terampil, dan berkarakter yang diamanatkan olehpancasila dalam UUD 1945.

Akan tetapi permasalahan pada pembelajaran pada mata pelajaran Pendidikan Kewarganegaraan adalah monotonnya pembelajaran, sehingga menjadikan siswa bosan dalam belajar dan berpengaruh terhadap hasil belajarnya. Pembelajaran masih didominasi oleh guru sebagai pusat pembelajaran, serta masih menggunakan model pembelajaran yang biasa sehingga terjadi konsep yang sulit dipahami oleh siswa.

Berdasarkan pengalaman peneliti ketika melaksanakan mata kuliah pelaksanaan praktek lapangan (PPL) di kelas III SD Negeri 79 Pekanbaru, rendahnya hasil belajar di sebabkan oleh siswa pada saat proses pembelajaran berlangsung tidak fokus terhadap guru yang sedang menjelaskan materi pelajaran, karena guru yang masih menerapkan metode ceramah dalam mengajar sehingga guru yang lebih aktif dari pada siswa sehingga siswa merasa bosan pada saat pembelajaran berlangsung, proses pembelajaran yang berlangsung masih berpusat pada guru, siswa kurang dilibatkan untuk menggali informasi sendiri, menemukan konsep sendiri atau mencari sumber belajar lain selain yang diberikan guru, dan dalam pembelajaran guru tidak menggunakan model pembelajaran sehingga kurang menarik perhatian siswa.

Pembelajaran yang melibatkan siswa secara aktif, kreatif, dan menyenangkan perlu diterapkan sebagai solusi dari kesenjangan yang ada. Salah satu model pembelajaran yang berpusat pada siswa adalah model pembelajaran kooperatif. Menurut Johnson (Saputro, 2014) pembelajaran kooperatif adalah kegiatan belajar mengajar secara kelompok-kelompok kecil, siswa belajar dan bekerja sama untuk sampai kepada pengalaman belajar, baik pengalaman individu maupun pengalaman kelompok. Model pembelajaran kooperatif ini merupakan salah satu model pembelajaran yang menggunakan metode pembelajaran aktif. Menurut Zaini (Katmuji, 2017) dengan pembelajaran aktif ini, siswa diajak untuk turut serta dalam semua proses pembelajaran, tidak hanya mental akan tetapi juga melibatkan fisik. Melalui model pembelajaran tersebut, siswa dapat merasakan suasana yang lebih menyenangkan sehingga hasil belajar mendapatkan hasil yang maksimal.

Model pembelajaran kooperatif tipe make a match adalah sejenis permainan tempat siswa harus menemukan pasangannya (Ratna Zawil, n.d.). Pembelajaran yang masih berpusat kepada guru mengakibatkan interaksi antara guru bersama siswa jarang terjadi, sehingga siswa merasa jenuh dalam proses pembelajaran (Dewita, Kurniaman, $\&$ Witri, 2015).

Lain halnya jika di terapkan model pembelajaran kooperatif tipe make a match yang ,mana siswa akan lebih aktif dalam proses pembelajaran sehingga siswa tidak merasa jenuh. Prinsip dasar Make a Match adalah siswa menemukan atau mencocokkan pasangan saat mereka sedang mempelajari suatu konsep atau tertentu topik dalam suasana kelas yang menarik (Irwanto \& Nurpahmi Sitti, 2018).Sejalan menurut pendapat (Fatturahman Muhammad, 2013) keunggulan model ini adalah siswa mencari pasangan sambil belajar mengenai suatu konsep atau topik dalam suasana menyenangkan. Model pembelajaran kooperatif tipe make a match termasukmodel pembelajaran yang menyenangkan karena siswa terjun langsung dalam materi yang di berikan dan mengembangkan materi yang akan di diskusikan bersama pasangannya. Membuat aktivitas belajar siswa dapat meningkat, karena ada unsur permainan di dalam model make a match yang dapat membangkitkan kreativitas dan kerjasama siswa antara pemegang kartu pertanyaan dan kartu jawaban. Dalam model ini siswa harus mengerjakan banyak tugas. Siswa harus menggunakan ide, mengkaji gagasan, memecahkan masalah, dan menerapkannya dalam pembelajaran. Belajar juga gesit, menyenangkan, bersemangat dan penuh motivasi. Siswa bahkan sering meninggalkan tempat duduk mereka, bergerak 
leluasa dan berpikir keras (Katmuji, 2017).

Berdasarkan masalah yang telah di paparkan tersebut, penulis melakukan penelitian dengan menggunakan model pembelajaran tersebut yang tujuannya untuk meingkatkan hasil belajar PKn siswa kelas III SD Negeri 188 Pekanbaru.

\section{METODE PENELITIAN}

Penelitian ini di laksanakan di SD Negeri 188 Pekanbaru pada semester genap tahun ajaran 2018/2019. Penelitian ini di lakukan pada bulan Februari 2019. Rancangan penelitian yang di lakukan adalah penelitian tindakan kelas (PTK) atau classroom action research. Penelitian

tindakan kelas adalah penelitian yang di lakukan oleh guru di kelasnya sendiri melalui refleksi diri dengan tujuan untuk memperbaiki kinerjannya sehingga hasil belajar siswa meningkat (Akib, dkk, 2008: 3).

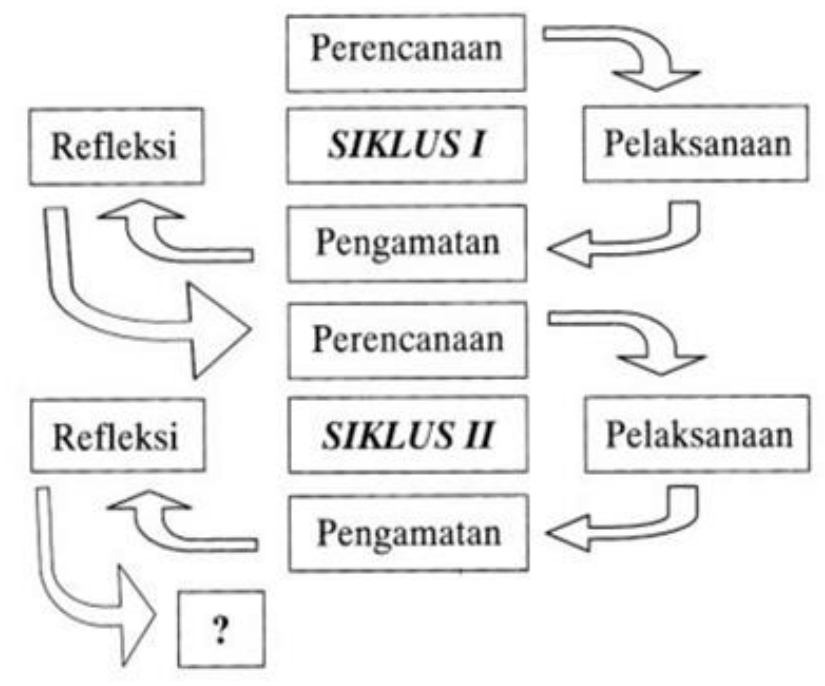

Gambar 1. Tahapan Penelitian Tindakan Kelas

Subjek penelitian ini adalah siswa kelas III SD Negeri 188 Pekanbaru dengan jumlah siswa 40 orang yang terdiri dari 19 orang laki-laki dan 21 perempuan.

Instrumen dalam penelitian ini yaitu perangkat pembelajaran yang terdiri dari Silabus, Rencana Pelaksanaan Pembelajaran (RPP), dan Lembar Kerja Siswa (LKS). Kemudian instrumen pengumpulan data yang terdiri dari lembar observasi, tes, dan dokumentasi. Peneliti juga menyiapkan instrumen pengumpulan data berupa lembar observasi aktivitas guru dan aktivitas siswa serta soal tes hasil belajar Pendidikan Kewarganegaraan yang telah di susun berdasarkan kisi-kisi soal. Teknik pengumpulan data pada penelitian ini adalah teknik pengamatan aktivitas guru dan aktivitas siswa serta teknik tes hasil belajar.

Data yang di peroleh dari penelitian ini di analisis dengan menggunakan teknik penelitian deskriptif dengan penghitungan persentase. Adapun proses pelaksanaannya adalah apabila seluruh data telah terkumpul lalu akan dikelompokkan ke dalam jenis data masing-masing yaitu data kualitatif dan data kuantitatif. Data kualitatif akan di gambarkan dengan analisis deskriptif atau di gambarkan dengan kata-kata. Sedangkan data kuantitatif akan di analisis dengan menggunakan rumus.

Analisis dalam penelitian ini menggunakan teknik analisis data, adapun data yang di peroleh meliputi :

Analisis Aktivitas Guru dan Aktivitas Siswa. 
DOI : http://dx.doi.org/10.33578/jpfkip.v8i1.7627

ISSN : 2303-1514 | E-ISSN : 2598-5949

https://primary.ejournal.unri.ac.id/index.php/JPFKIP

$\mathrm{NP}=\mathrm{R} / \mathrm{SM} \mathrm{X} 100$

(Purwanto, 2013: 102)

Keterangan :
$\mathrm{NP}=$ Nilai persen yang dicari atau diharapkan

$\mathrm{R}=$ Skor mentah yang di peroleh guru atau siswa

$\mathrm{SM}=$ Skor maksimum dari aktivitas guru atau aktivitassiswa

Tabel 1. Interval dan Kategori Aktivitas Guru dan Aktivitas Siswa

\begin{tabular}{cc}
\hline Presentase Interval $(\boldsymbol{\%})$ & Kategori \\
\hline $86-100$ & Sangat Baik \\
$76-85$ & Baik \\
$60-75$ & Cukup \\
$55-59$ & Kurang \\
$<54$ & Kurang Sekali \\
\hline
\end{tabular}

Analisis Data Hasil Belajar PKn Siswa

$$
\mathrm{S}=\frac{\mathrm{R}}{\mathrm{N}} \times 100
$$

(Purwanto, 2013: 112)

Keterangan :

$\mathrm{S}=$ Nilai yang di harapkan (di cari)

$\mathrm{R}=$ Jumlah skor dari item atau soal yang di jawab benar

$\mathrm{N}=$ Skor maksimum dari tes tersebut
Peningkatan Hasil Belajar

$$
P=\frac{\text { Posrate }- \text { Baserate }}{\text { Baserate }} \times 100 \%
$$

(Aqib , dkk., 2011: 53)

Keterangan :

$\mathrm{P} \quad=$ Persentase peningkatan

Posrate = Nilai sesudah di berikan tindakan

Baserate $=$ Nilai sebelum tindakan

\section{HASIL DAN PEMBAHASAN}

Proses pembelajaran penelitian tindakan kelas pada setiap pertemuan di siklus I dan siklus II dilaksanakan sesuai fase-fase model pembelajaran kooperatif. Pada setiap pertemuan dalam penelitian tindakan kelas, fase - fase guru

dalam melaksanakan penelitian tindakan kelas antara lain sebagai berikut :

1. Guru menyampaikan tujuan dan memotivasi peserta didik seperti gambar di bawah ini :

\section{Gambar 1. Menyampaikan Tujuan dan Memotivasi Peserta Didik}
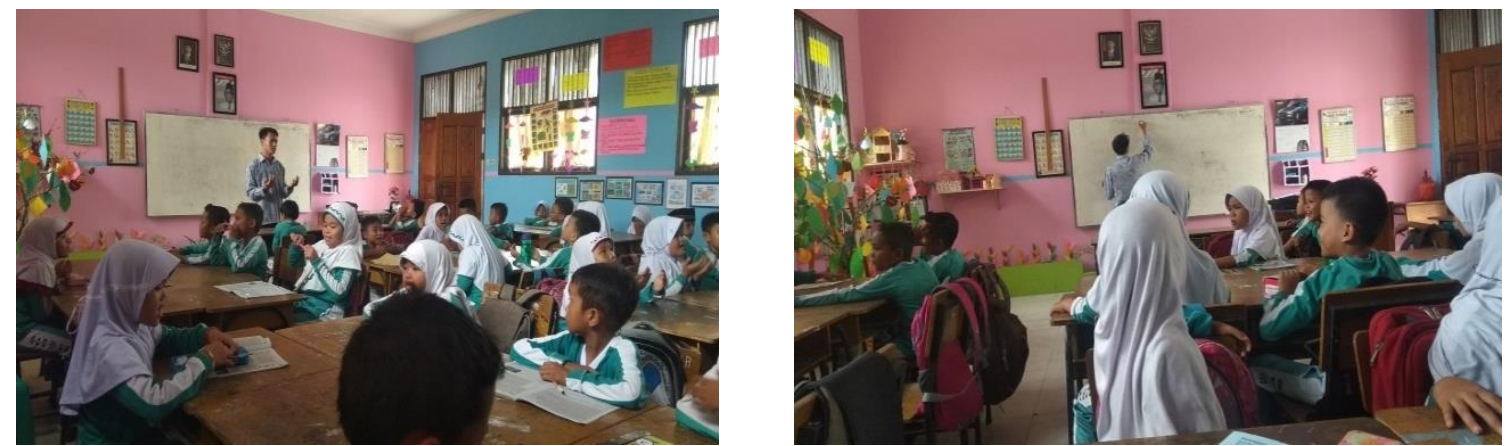


\section{PRIMARY : JURNAL PENDIDIKAN GURU SEKOLAH DASAR \\ Volume 8 Nomor 2 Oktober 2019 \\ DOI : http://dx.doi.org/10.33578/jpfkip.v8i1.7627 \\ ISSN : 2303-1514 | E-ISSN : 2598-5949 \\ https://primary.ejournal.unri.ac.id/index.php/JPFKIP}

Pada fase ini guru sebelum memulai proses pembelajaran, guru membuka pembelajaran dengan mengucapkan salam, kemudian meminta ketua kelas untuk memimpin teman-temannya membaca doa pelajaran secara bersama-sama, selanjutnya guru mengabsen siswa. Guru kemudian melakukan appersepsi melalui pertanyaan mengenai materi pelajaran.

2. Guru menyajikan informasi seperti gambar di bawah ini:

Gambar 2. Menyajikan Informasi

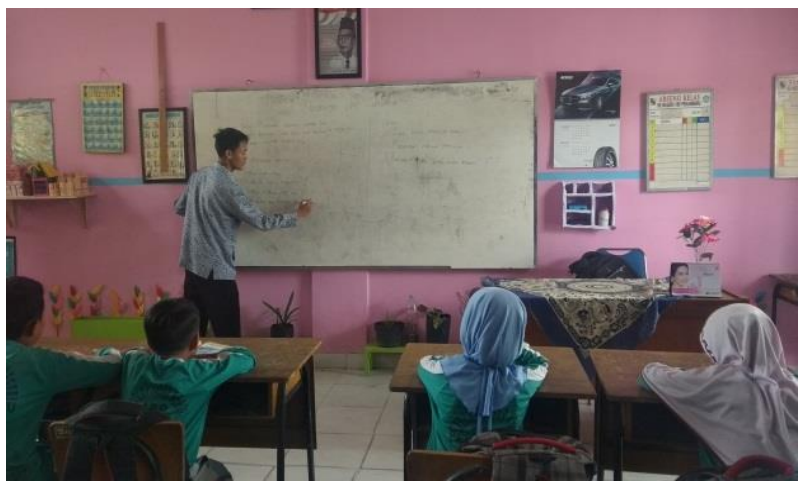

Guru menjelaskan materi pelajaran. Kemudian guru menyampaikan kepada siswa setelah guru menjelaskan materi akan ada sebuah permainan, sehingga siswa merasa senang dan tertarik untuk menerima bentuk permainan dari guru tersebut. Setelah itu guru menjelaskan langkah- langkah pelaksanaan model pembelajarat tersebut.

3. Guru mengorganisir siswa ke dalam kelompok belajar seperti gambar di bawah ini :

\section{Gambar 3. Mengorganisir Siswa ke Dalam Kelompok Belajar}

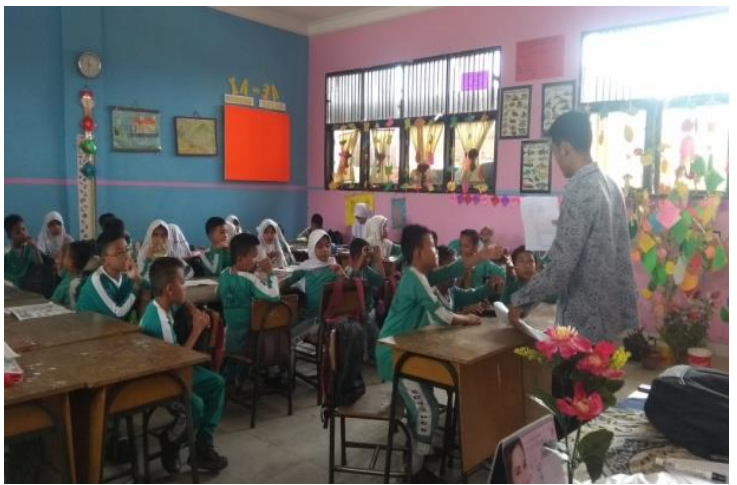

Guru pada fase ini membentuk siswa kedalam 8 kelompok, masing-masing kelompok terdiri dari 5 orang siswa. Pada saat pembentukan kelompok guru menentukan lokasi tempat duduk kelompok kemudian kelompok yang telah di tentukan guru secara bergantian langsung ke lokasi tempat duduk kelompoknya yang telah di tentukan tersebut. Hal ini juga mengurangi

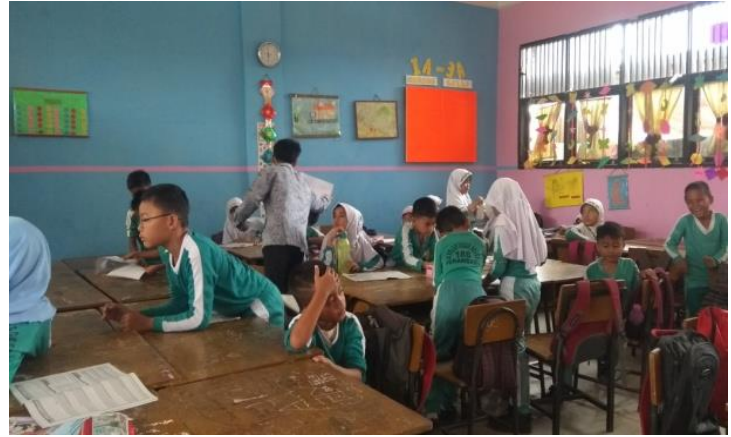

keributan dalam pembentukan kelompok. Setelah siswa duduk ke dalam kelompok masing-masing, guru membagikan lembar kerja siswa kepada setiap kelompok, kemudian guru menjelaskan cara menjawab soal pada lembar kerja siswa tersebut.

4. Guru membantu kerja tim dan belajar seperti gambar di bawah ini : 


\section{PRIMARY : JURNAL PENDIDIKAN GURU SEKOLAH DASAR \\ Volume 8 Nomor 2 Oktober 2019 \\ DOI : http://dx.doi.org/10.33578/jpfkip.v8i1.7627 \\ ISSN : 2303-1514 | E-ISSN : 2598-5949 \\ https://primary.ejournal.unri.ac.id/index.php/JPFKIP}

\section{Gambar 4. Membantu Kerja Tim}

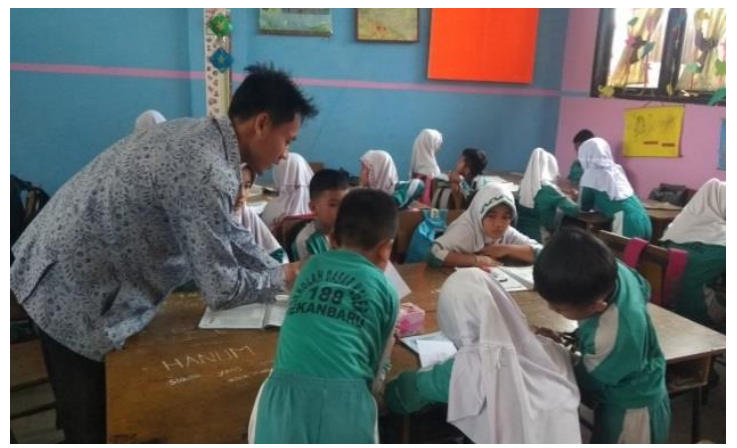

Guru berjalan ke setiap kelompok untuk mengawasi dan membimbing kelompok yang mengalami kesulitan dalam menjawab soal pada lembar kerja siswa tersebut. Pada pertemuan pertama siklus I masih banyak siswa yang belum paham menjawab soal pada lembar kerja siswa pada kelompoknya, sehingga guru menjelasakannya di setiap kelompok. guru meminta perwakilan di setiap kelompok untuk mengumpulkan lembar kerja siswa jika sudah di jawab oleh siswa.

5. Guru melakukan evaluasi seperti gambar di bawah ini:

\section{Gambar 5. Melakukan Evaluasi}
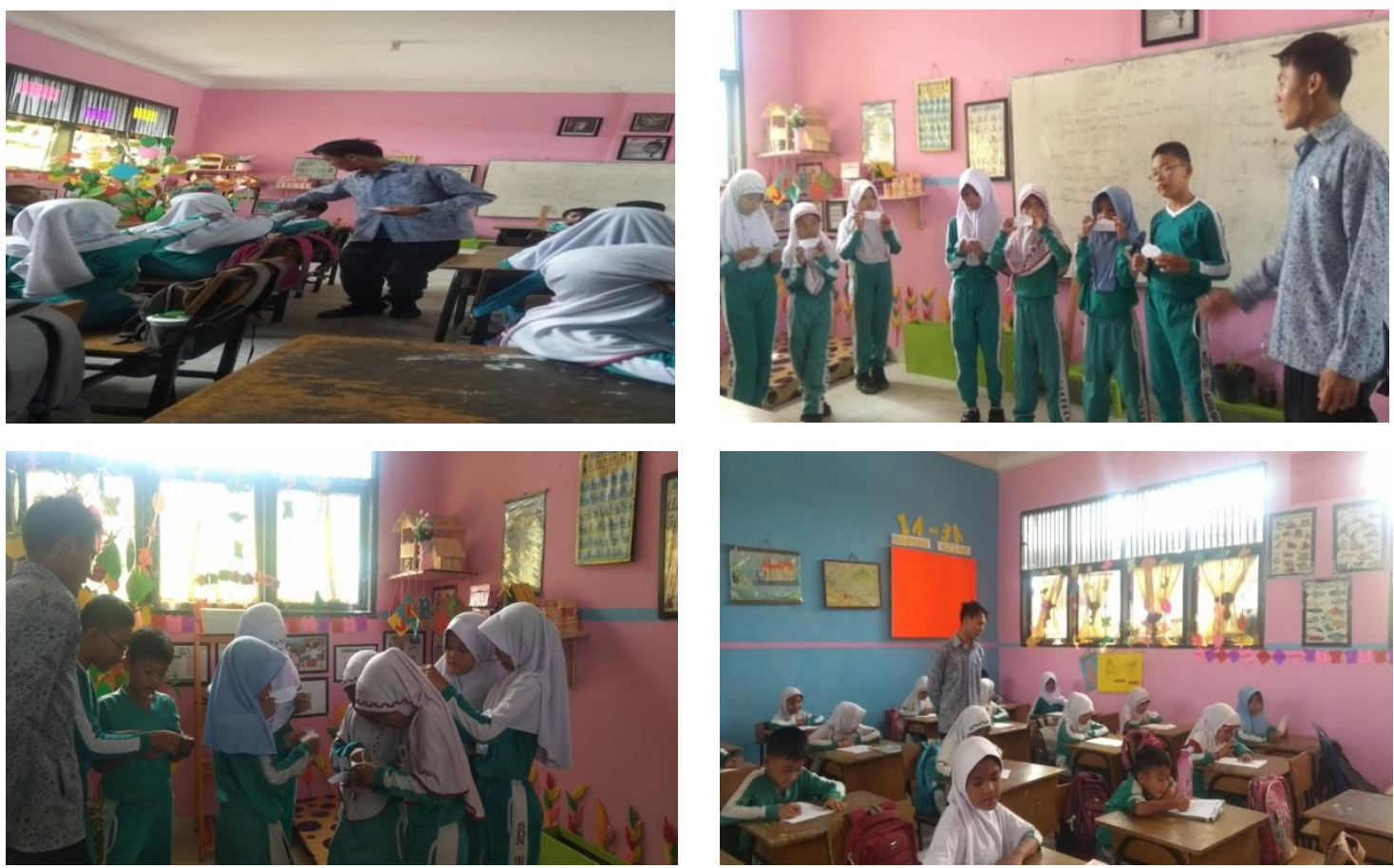

Pada fase ini guru bersama siswa melakukan pembelajaran model kooperatif tipe make a match. Guru menyiapkan 40 kartu terdiri

dari 20 kartu soal dan 20 kartu jawaban yang berisi konsep atau topik seputar materi yang telah di pelajari pada pertemuan tersebut yang cocok 


\section{PRIMARY : JURNAL PENDIDIKAN GURU SEKOLAH DASAR \\ Volume 8 Nomor 2 Oktober 2019 \\ DOI : http://dx.doi.org/10.33578/jpfkip.v8i1.7627 \\ ISSN : 2303-1514 | E-ISSN : 2598-5949 \\ https://primary.ejournal.unri.ac.id/index.php/JPFKIP}

untuk sesi review. Guru memberikan satu kartu soal kepada setiap siswa dikelompok 1, kelompok 3, kelompok 5, dan dikelompok 7, satu kartu jawaban di berikan kepada setiap siswa dikelompok 2, kelompok 4, kelompok

Guru kemudian meminta siswa yang memegang kartu soal berbaris sejajar dan siswa memegang kartu jawaban juga berbaris sejajar dan siswa memegang kartu soal dan kartu jawaban saling berhadapan. Setelah itu guru meminta siswa yang memegang kartu jawaban membacakan kartu jawaban secara acak dengan bergantian, hal ini bertujuan sebagai penanda bagi siswa yang memegang kartu soal agar mudah mencocokan kartu soal yang di pegangnya tersebut. Kemudian setelah kartu jawaban di bacakan, siswa yang pegang kartu soal mencari jawaban yang cocok kepada siswa yang pegang kartu jawaban.

Setelah satu babak, permainan make a match di lakukan lagi dengan mengganti siswa di kelompok yang pegang kartu soal selanjutnya memegang kartu jawaban dan siswa di kelompok yang pegang kartu jawaban selanjutnya memegang kartu soal. Tata cara permainannya di lakukan seperti sebelumnnya.

6. Guru memberikan pengakuan atau
penghargaan seperti gambar di bawah ini :

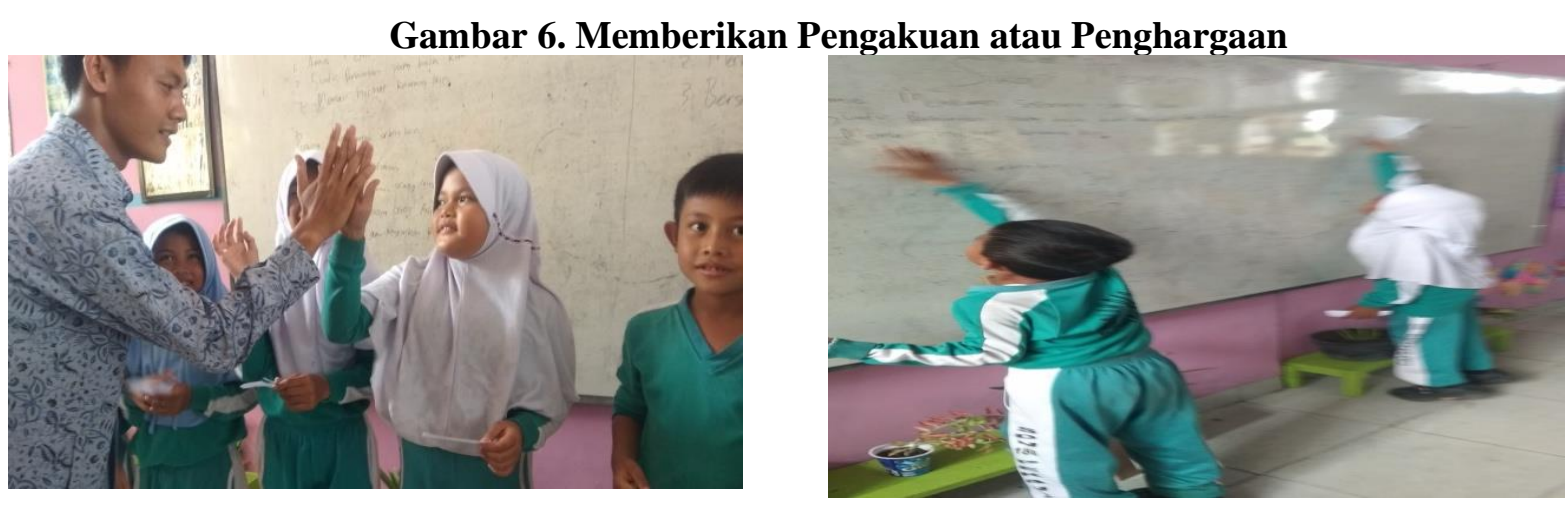

Guru menghitung skor perkembangan individu dan kelompok kemudian guru meminta kelompok terbaik untuk berdiri dan meminta siswa lain memberikan tepuk tangan., dan kelompok yang tidak bisa mencocokan kartu tersebut maka diberi hukuman yang telah di sepakati bersama.

\begin{abstract}
Aktivitas Guru dan Aktivitas Siswa
Berdasarkan hasil pengamatan yang di lakukan oleh observer, aktivitas guru dan aktivitas siswa selama pelaksanaan pembelajaran dengan penerapan model pembelajaran kooperatif tipe make a match pada siklus I dan II dapat di lihat pada tabel berikut ini:
\end{abstract}

Tabel 2. Hasil Lembar Observasi Aktivitas Guru Siklus I dan Siklus II.

\begin{tabular}{ccccc}
\hline & Siklus I & \multicolumn{3}{c}{ Siklus II } \\
\hline Pertemuan & I & II & I & II \\
Jumlah Skor & 15 & 19 & 20 & 23 \\
Persentase & $62.5 \%$ & $79.16 \%$ & $83.33 \%$ & $95.83 \%$ \\
Kategori & Cukup & Baik & Baik & Sangat Baik \\
\hline
\end{tabular}

Berdasarkan tabel 2 di atas, pada siklus I pertemuan pertama rata-rata persentase aktivitas guru kategori cukup, karena peneliti masih belum maksimal dalam menguasai kelas. Peneliti masih mengalami kesulitan dalam pembentukan kelompok. Peneliti harus membimbing ke setiap kelompok dalam menjawab soal pada lembar kerja siswa karena semua kelompok belum paham 
peneliti juga masih kurang terbiasa dengan langkah-langkah model pembelajaran kooperatif tipe make a match, sehingga dalam pelaksanaannya kurang maksimal dan menyebabkan suasana kelas ribut.

Pada siklus I pertemuan kedua persentase aktivitas guru mengalami peningkatan dengan kategori baik. Pada pertemuan kedua ini peneliti masih membimbing siswa dalam pembentukan kelompok. Pelaksanaan model pembelajaran kooperatif tipe make a match belum terlaksana dengan baik karena masih ada siswa yang belum paham cara permainan make a match.. Peneliti masih membimbing beberapa kelompok dalam menjawab soal pada lembar kerja siswa yang mengalami kesulitan.

Pada siklus II pertemuan pertama persentase aktivitas guru telah mengalami peningkatan dengan kategori baik dari pada pertemuan-pertemuan pada siklus I. Pada pertemuan ini peneliti sudah mulai mampu melaksanakan model pembelajaran kooperatif tipe make a match sehingga suasana kelas tidak terlalu ribut lagi.

Sedangkan pada siklus II pertemuan kedua persentase aktivitas guru sudah terlihat bagus dengan kategori sangat baik. Pada pertemuan ini peneliti sudah mampu menguasai kelas. Peneliti tidak mengalami kesulitan dalam pembentukan kelompok karena sudah mulai mudah dibentuk dan teratur. Pada pelaksanaan pembelajaran model kooperatif tipe make a match peneliti tidak menjelaskan cara pelaksanaanya lagi. Peneliti tidak terlalu membimbing kelompok ketika menjawab soal pada lembar kerja siswa.

Tabel 3. Hasil Lembar Observasi Aktivitas Siswa Siklus I dan Siklus II.

\begin{tabular}{ccccc}
\hline & Siklus I & \multicolumn{3}{c}{ Siklus II } \\
\hline Pertemuan & I & II & I & II \\
Jumlah Skor & 15 & 19 & 22 & 23 \\
Persentase & $62.5 \%$ & $79.16 \%$ & $91.66 \%$ & $95.83 \%$ \\
Kategori & Cukup & Baik & Sangat Baik & Sangat Baik \\
\hline
\end{tabular}

Berdasarkan tabel 3 di atas, aktivitas siswa dalam empat kali pertemuan secara umum menunjukkan mengalami peningkatan. Pada siklus I pertemuan pertama aktivitas siswa kategori cukup. Hal ini karena dalam proses pembelajaran pertama kali siswa belum paham dalam pelaksanaan model pembelajaran kooperatif tipe make a match. Ketika menjawab soal pada lembar kerja siswa disetiap kelompok masih membutuhkan bimbingan dari peneliti.

Pada siklus I pertemuan kedua aktivitas siswa mengalami peningkatan dengan kategori baik. Hal ini terlihat pada pelaksanaan model pembelajaran kooperatif tipe make a match sudah banyak siswa yang mulai paham dalam pelaksanaannya. Ketika menjawab soal pada lebar kerja siswa tidak semua kelompok membutuhkan bimbingan dari peneliti.

Pada siklus II pertemuan pertama aktivitas siswa mengalami peningkatan dengan kategori sangat baik dari pertemuan pada siklus I. Pada pertemuan ini hanya beberapa siswa dalam menjawab soal pada lebar kerja siswa yang mengalami kesulitan, sedangkan dalam pelaksanaan model pembelajaran kooperatif tipe make a match siswa sudah paham karena sudah mulai terbiasa.

Sedangkan pada siklus II pertemuan kedua aktivitas siswa kembali mengalami peningkatan dengan kategori sangat baik. Hal ini karena siswa sudah terbiasa melakukan proses pembelajaran dengan model pembelajaran kooperatif tipe make a match sehingga siswa paham. Siswa sudah bisa membentuk kelompoknyawajan sendiri, siswa sudah paham dalam menjawab soal pada lembar kerja siswa.

Pembelajaran pada siklus I pertemuan pertama membahas materi tentang "sikap menghargai orang lain " ,dan indikator dari mempelajari materi tersebut yaitu menjelaskan pentingnya perilaku yang mencerminkan harga diri dan menyebutkan contohnya. Pada siklus I pertemuan pertama rata-rata persentase aktivitas guru $62.5 \%$ kategori cukup, dan aktivitas siswa 


\section{PRIMARY : JURNAL PENDIDIKAN GURU SEKOLAH DASAR \\ Volume 8 Nomor 2 Oktober 2019 \\ DOI : http://dx.doi.org/10.33578/jpfkip.v8i1.7627 \\ ISSN : 2303-1514 | E-ISSN : 2598-5949 \\ https://primary.ejournal.unri.ac.id/index.php/JPFKIP}

memperoleh persentase $62.5 \%$ kategori cukup. karena guru dan siswa belum sepenuhnya menjalankan model pembelajaran kooperatif tipe make a match atau masih pengenalan, karena sebelumnya belum pernah melaksanakan pembelajaran kooperatif tipe make a match.

Pembelajaran pada siklus I pertemuan kedua membahas materi tentang "perilaku yang mencerminkan harga diri," dan indikator dari mempelajari materi tersebut yaitu menampilkan perilaku yang mencerminkan harga diri. Pada pertemuan kedua ini, persentase aktivitas guru mengalami peningkatan dengan persentase 79.16\% kategori baik. Aktivitas siswa mengalami peningkatan dengan memperoleh persentase $72.16 \%$ kategori baik. Pada pertemuan kedua ini guru telah memperbaiki ke kurangan pada siklus I pertemuan pertama sehingga berdampak baik terhadap aktivitas siwa.

Pada siklus II pertemuan pertama membahas materi tentang "ciri khas bangsa Indonesia ", dan indikator dari mempelajari materi tersebut yaitu mengindentifikasi keanekaragaman budaya dan kekayaan alam Indonesia. Pada pertemuan pertama di siklus II persentase aktivitas guru telah mengalami peningkatan dengan persentase $83.33 \%$ kategori baik. Aktivitas siswa memperoleh persentase $91.66 \%$ kategori sangat baik. Pada pertemuan ini guru hanya mengalami kesulitan dalam kelompok yang masih perlu bimbingan dari guru.

Sedangkan pada siklus II pertemuan kedua membahas materi tentang "wujud rasa bangga sebagai anak bangsa Indonesia " ,dan indikator dari mempelajari materi tersebut yaitu memiliki rasa bangga sebagai anak bangsa Indonesia. Pada pertemuan kedua siklus II persentase aktivitas guru sudah terlihat bagus dengan kategori sangat baik. Aktivitas siswa memperoleh persentase $95.83 \%$ kategori sangat baik. Pada pertemuan ini guru sudah mampu dan terbiasa dalam pelaksanaan model kooperatif tipe make a match tersebut.

\section{Hasil Belajar}

Untuk mengetahui peningkatan hasil belajar siswa melalui penerapan model pembelajaran kooperatif tipe make a match pada siswa kelas III SD Negeri 188 Pekanbaru dapat di lihat pada tabel 4 berikut ini:

Tabel 4. Peningkatan Rata-Rata Hasil Belajar PKn Siswa Kelas III SD Negeri 188 Pekanbaru

\begin{tabular}{llllll}
\hline No & Data & $\begin{array}{l}\text { Jumlah } \\
\text { Siswa }\end{array}$ & $\begin{array}{l}\text { Rata- } \\
\text { Rata }\end{array}$ & \multicolumn{2}{l}{$\begin{array}{l}\text { Peningkatan Hasil } \\
\text { Belajar Siswa }\end{array}$} \\
\cline { 3 - 6 } & & & & & \\
& & & 68.25 & & \\
\hline 1. & Skor Dasar & 40 & 76.87 & $12.63 \%$ & \\
2. & UH I & 40 & 81.5 & & $19.41 \%$ \\
3. & UH II & 40 & SD-UH II \\
\hline
\end{tabular}

Pada sebelum tindakan nilai rata-rata di peroleh adalah 68.25. Kemudian pada siklus I meningkat menjadi 76.87 dan siklus II menjadi 81.5. Rata - rata hasil belajar meningkat dikarenakan pada siklus I sudah melakukan tindakan, tetapi belum keseluruhan siswa yang tuntas, pada ketuntasan klasikal sebelum di lakukan tindakan hanya diperoleh $72.5 \%$ kategori tidak tuntas dengan rata-rata 76.87. Karena siklus I belum tuntas Sehingga di lakukan kembali tindakan pada siklus II, pada siklus ini baru diperoleh ketuntasan klasikal $87.5 \%$ dan kategori tuntas dengan rata-rata 81.5.

\section{Pembahasan}

\section{Aktivitas Guru}

Pada pertemuan pertama siklus I aktivitas guru berkategori cukup, hal ini dikarenakan guru masih belum maksimal dalam menguasai kelas. Guru masih mengalami kesulitan dalam pembentukan kelompok. Guru harus membimbing ke setiap kelompok dalam menjawab soal pada lembar kerja siswa karena semua kelompok belum 
paham. Guru juga masih kurang terbiasa dengan langkah-langkah model pembelajaran kooperatif tipe make a match, sehingga dalam pelaksanaannya kurang maksimal dan menyebabkan suasana kelas ribut.

Pada pertemuan kedua siklus I mengalami peningkatan aktivitas guru masih berkategori baik. Guru masih membimbing siswa dalam pembentukan kelompok. Pelaksanaan model pembelajaran kooperatif tipemake a match belum terlaksana dengan baik karena masih ada siswa yang belum paham cara permainan make a match. Guru masih membimbing beberapa kelompok dalam menjawab soal pada lembar kerja siswa yang mengalami kesulitan.

Selanjutnya pada pertemuan pertama siklus II mengalami peningkatan berkategori baik. Hal ini dikarenakan guru sudah mulai terbiasa melaksanakan pembelajaran kooperatif tipe make a match. Sehingga pada pertemuan kedua siklus II aktivitas guru memperoleh nilai berkategori sangat baik. Pada pertemuan ini guru sudah mampu menguasai kelas. Guru tidak mengalami kesulitan dalam pembentukan kelompok karena sudah mulai mudah dibentuk dan teratur. Pada pelaksanaan pembelajaran model kooperatif tipe make a match guru tidak menjelaskan cara pelaksanaanya lagi. Guru tidak terlalu membimbing kelompok ketika menjawab soal pada lembar kerja siswa. Hasil aktivitas guru pada setiap pertemuan mengalami peningkatan. Peningkatan ini dikarenakan adanya perubahan dan perbaikan dalam penerapan model pembelajaran kooperatif tipe make a match pada setiap pertemuan.

\section{Aktivitas Siswa}

Pada pertemuan pertama siklus I siswa masih belum mengerti dengan model pembelajaran kooperatif tipe make a match. Sehingga aktivitas pada pertemuan pertama siklus I memperoleh kategori cukup saja. Hal ini karena dalam proses pembelajaran pertama kali siswa belum paham dalam pelaksanaan model pembelajaran kooperatif tipe make a match. Ketika menjawab soal pada lembar kerja siswa di setiap kelompok masih membutuhkan bimbingan dari peneliti. Namun, pada pertemuan kedua siklus I terjadi peningkatan menjadi kategori baik.
Hal ini terlihat pada pelaksanaan model pembelajaran kooperatif tipe make a match sudah banyak siswa yang mulai paham dalam pelaksanaannya. Ketika menjawab soal pada lebar kerja siswa tidak semua kelompok membutuhkan bimbingan dari guru.

Pada pertemuan pertama siklus II terjadi peningkatan menjadi kategori sangat baik.Pada pertemuan ini hanya beberapa siswa dalam menjawab soal pada lebar kerja siswa yang mengalami kesulitan, sedangkan dalam pelaksanaan model pembelajaran kooperatif tipe make a match siswa sudah paham karena sudah mulai terbiasa.

Pada pertemuan kedua siklus II terjadi peningkatan menjadi kategori sangat baik. Hal ini menandakan bahwa adanya perubahan tingkah laku siswa selama proses pembelajaran kooperatif tipe make a match. Peningkatan-peningkatan tersebut ditandai dengan siswa mulai memahami langkah-langkah model pembelajaran kooperatif tipe make a match. Hal ini menunjukkan bahwa model pembelajaran kooperatif tipe make a match bisa diterapkan secara maksimal pada siswa kelas III SD Negeri 188 Pekanbaru. Aktivitas siswa dalam pelaksanaan model pembelajaran kooperatif tipe make amatch pada setiap pertemuan mengalami peningkatan. Hal ini dikarenakan siswa sudah mulai memahami dan terbiasa penerapan dengan model pembelajaran kooperatif tipe make a match.

\section{Hasil Belajar}

Hasil belajar siswa sebelum melaksanakan model pembelajaran kooperatif tipe make a match terdapat skor dasar dengan rata-rata 68.25. Hal tersebut terjadi karena guru dalam proses pembelajaran masih menggunakan metode ceramah, yaitu guru hanya menjelaskan materi pelajaran sehingga hanya guru yang terlihat aktif dalam proses pembelajaran tersebut, sedangkan siswa hanya duduk mendengarkan penjelasan guru. Kemudian guru juga tidak melakukan diskusi bersama siswa, guru tidak menggunakan model pembelajaran yang inovatif sehingga menyebabkan siswa tidak aktif dalam proses pembelajaran yang berdampak terhadap hasil belajar siswa tersebut. 
Proses pembelajaran setelah menggunakan model kooperatif tipe make a match memperoleh hasil dengan rata-rata ulangan harian I menjadi 76.87dan rata-rata ulangan harian II menjadi 81.5. Peningkatan tersebut terjadi karena guru telah menerapkan model pembelajaran yang inovatif salah satunya yaitu model kooperatif tipe make a match. Sehingga dalam proses pembelajaran dapat membuat siswa aktif, kompak dan bertanggung jawab terhadap tugas yang di berikan guru.

Hasil belajar siswa sudah mendapat nilai yang diharapkan. Hal ini di karenakan semua siswa mengikuti secara baik model pembelajaran kooperatif tipe make a match. Siswa belajar dengan bersemangat, karena model pembelajaran kooperatif tipe make a match adalah model pembelajaran yang baru mereka alami sehingga

\section{SIMPULAN DAN REKOMENDASI}

Aktivitas guru pada siklus I pertemuan 1 sebesar $62.5 \%$ dengan kategori cukup, pada pertemuan 2 sebesar $76.16 \%$ dengan kategori baik dan siklus II pertemuan 1 sebesar $83.33 \%$ dengan kategori baik dan pertemuan 2 sebesar $95.83 \%$ dengan kategori sangat baik. Berdasarkan hasil tersebut terjadi peningkatan dari siklus I ke siklus II. Aktivitas siswa siklus I pertemuan 1 sebesar $62.5 \%$ dengan kategori sedang, pada pertemuan 2 sebesar $79.16 \%$ dengan kategori baik, siklus II pertemuan 1 sebesar $91.66 \%$ dengan kategori sangat baik dan pada pertemuan 2 sebesar $95.83 \%$ dengan kategori sangat baik.

Hasil belajar siswa sebelum tindakan dengan rata-rata sebesar 68.25 dengan kategori kurang, kemudian pada siklus I mendapatkan rata-

\section{DAFTAR PUSTAKA}

Akib, Z., dkk. (2011). Penelitian Tindakan Kelas Untuk Guru SMP, SMA, SMK. Bandung: Yrama Widya.

Arikunto, S., dkk. (2015). Penelitian Tindakan Kelas. Jakarta: Bumi Aksara.

Dewita, S. N., Kurniaman, O., \& Witri, G. (2015). Penerapan Model Pembelajaran Kooperatif Tipe Make A Match Untuk Meningkatkan motivasi untuk belajar mereka sangat tinggi pada setiap ulangan harian disetiap siklus.

Setelah di lakukan ulangan harian di setiap siklus, nilai rata-rata siswa mengalami peningkatan yang signifikan, yaitu dari skor dasar ke ulangan harian I peningkatannya adalah $12.63 \%$. Kemudian skor dasar ke ulangan harian II adalah $19.41 \%$. Peningkatan klasikal juga mengalami peningkatan yang signifikan dari setiap ulangan harian di setiap siklus. Peningkatan klasikal pada skor dasar adalah $42.5 \%$, meningkat di ulangan harian I menjadi $72.5 \%$ dan pada ulangan harian II meningkat menjadi $87.5 \%$. Hal ini menunjukkan bahwa keberhasilan belajar siswa di karenakan model pembelajaran kooperatif tipe make a match secara keseluruhan terlaksana dengan baik sehingga dapat meningkatkan hasil belajar siswa.

rata 72.5 dan pada siklus II mendapatkan rata-rata kelas 81.5.

Berdasarkan penelitian yang telah di lakukan, maka peneliti memberikan beberapa rekomendasi yaitu: 1) Penerapan model kooperatif tipe make a match:ini di harapkan dapat menjadi salah satu alternatif pembelajaran. PKn disekolah guna untuk meningkatkan hasil belajar siswa, karena dengan model ini menuntut siswa untuk berperan aktif dalam proses pembelajaran. 2) Bagi peneliti yang ingin melakukan penelitian dengan tujuan untuk meningkatkan hasil belajar siswa, maka model pembelajaran kooperatif tipe make a match dapat di jadikan landasan berpijak untuk peneliti yang ingin menindak lanjuti penelitian ini dalam ruang lingkup yang lebih luas.

Hasil Belajar IPS Siswa Kelas III SD Negeri 001 Japura. English, Teaching, Learning and Research Journal), 3(2), 159-169.

Ernawati, L., Utami, S., \& Sabri, T. (2015). Penerapan Model Pembelajaran Kooperatif Tipe Make A Match Untuk Meningkatkan 
Hasil Belajar PKn Siswa. e-journal Boga, 4(1).

Fatturahman, M. (2013). Penggunaan Metode Make A Match Untuk Meningkatkan Motivasi Belajar PKn Pada Siswa Kelas IV SD Negeri Jetiskarangpung. Jurnal Pendidikan Sekolah Dasar, 3, 1-39.

Hidayah. N, Suharno, I. M. (2017). The Use of Cooperative Learning of Jigsaw-Type and Make A Match Type to Improve Students Activity. Nur Aini Wahyu Hidayah Suharno Mintasih Indriayu, 4(1), 25-30.

Irwanto, \& Nurpahmi Sitti. (2018). Using Make-a Match To Improve the Students' Reading Comprehension At Mts Guppi Samata Gowa. ETERNAL English, Teaching, Learning and Research Journal), 3(2), 159-169.

Katmuji. (2017). Penerapan Model Pembelajaran Make a Match Pada Materi Ajar Pkn Keputusan Bersama. Jurnal Inovasi Pembelajaran Karakter (JIPK), 2(1), 1-6.

Muslihah, Alpusari, M., \& N, L. (n.d.). Penerapan model pembelajaran kooperatif tipe Make a Match untuk meningkatkan kualitas pembelajaran IPS pada siswa kelas III SDN 028 Serusa Kecamatan Bangko Kabupaten Rokan Hilir. Jurnal Pendidikan Guru MI, 4(2), 179-188.

Ratna Zawil. (n.d.). Using Make A Match Technique To Teach Vocabulary. JINoP (Jurnal Inovasi Pembelajaran), 3(2), 311328.

Saputro, E. D. (2014). Upaya Meningkatkan Minat Belajar Siswa Pada Materi Hak Asasi Manusia (HAM) Dengan Menggunakan Metode Make A Match Pada Mata Pelajaran PKn Siswa Kelas X A SMA Negeri 1 Balong Ponorogo Tahun Pelajaran 2013/2014. Jurnal Pendidikan IPS, 2(2), 158-169. 